\title{
Portraits of 'angels': Some Ancient Near Eastern and Old Testament perspectives in relation to ATR belief system(s)
}

\author{
Prof Dirk J Human \\ Faculty of Theology and Religion, \\ University of Pretoria, South Africa \\ Email: dirk.human@up.ac.za \\ Orcid id: https://orcid.org/0000-0003-0346-4209 \\ DOI: https://doi.org/10.46222/pharosjot.102.11
}

\begin{abstract}
For the modern mind the notion of heavenly beings or 'angels' is an enigmatic and fascinating phenomenon. In the Ancient Near Eastern world and in the Hebrew Bible the word for 'angel', namely mal' āk, is widely attested and refers to both human and supernatural emissaries. The notion and function of angels as messenger-beings are evident. In the Israelite faith and their confession of a sole monotheistic God, Yahweh, several questions arise regarding these 'angels': who were these human and supernatural entities? In addition, the Hebrew Bible also recorded 'other' 'angel'-like beings, such as Seraphim and Cherubim. Then there was the 'angel' of Yahweh! Who was this figure, and what role did he play in the portrayal of the theologies of the Hebrew Bible? Were there fallen angels? And what has the Hebrew Bible to say about Satan?

Ultimately, perspectives on 'angels' in the Hebrew Bible are brought into relation with realities of the 'seen' and the 'unseen' in or from Africa in perspectives of the worldview of African Traditional Religions (ATR). Various categories and agents in African Traditional Religions and their belief systems are apparent. These include the Supreme Being (God), divinities, and spirits. The relationship between the Supreme Being and the other categories describe the character, nature and function of all these entities. Primary and minor divinities are distinguished. They are created, are derivations of God, receive functions to perform in the universe. Furthermore, they serve intermediatory functions between the Supreme Being (the 'unseen') and humankind (the 'seen'). Spirits are similarly 'created' entities. In many African narratives they are portrayed in human form, activities and personalities (a change from the 'unseen' into the 'seen'). Hereby the interaction between the 'seen' and the 'unseen' in African Traditional Religions remain real.
\end{abstract}

Keywords: angels, messenger-beings, Hebrew Bible, pantheon, African Religiosity, African Traditional Religions (ATR), Supreme Being, divinities, spirits.

\section{GOD, HEAVENLY BEINGS AND ANGELS IN THE HEBREW BIBLE}

\section{Introduction}

For the modern mind of the twenty-first century the notion of heavenly beings or 'angels' is still an enigmatic and fascinating phenomenon. It recalls the mystery and power(s) of a transcendent or 'unseen' world. Nonetheless, 'angels' are over millennia well-represented in the spheres and depictions of theology and religion or in different cultural realms. Their 
appearance, presence and function capture the imagination of human-kind, although these 'beings' are often described to be human. Question is: were angelic beings figures with wings and haloes, like in Raphael's paintings or not? Were they only spiritual beings or are they just mythological depictions of divine interventions and functions?

Recent knowledge about 'angels' is still vague, mysterious and elusive, despite the development of all the Natural, Human and Social Sciences and attempts to discover how they look like or what they do. These figures represent the mystery of the transcended 'unseen'. Nowhere in the Hebrew Bible do we find a systematic description of their origin, profile, being, function or status (Röttger, 1991:537-538). The Hebrew term for angel is mal' $\bar{a} k$ and appears 213x in the Hebrew Bible (Ficker 1984:901). Less appearances of angels characterise the earlier time period of Israelite history, while they appear to be more prominent in later (more recent) texts, after the Babylonian exile and Israel's encounter with Persian and Greek civilisations (after 538 BCE). Literature outside the Hebrew Bible from the $3^{\text {rd }}$ century $B C E$ to $1^{\text {st }}$ CE have more and different descriptions for angels (Newsome 1992:462). During this period there was a strong development in the understanding of angelology. Angelic figures were less prominent during the earlier part of Israelite history, when patriarchs, priests and prophets mediated between the Israelite god, Yahweh, and his people Israel. Angels' mediatory function was much stronger in and after the Babylonian exile ( $6^{\text {th }} \mathrm{BCE}$ ) when Israel was plunged into crises of life-endangering situations and had contact with nations like the Babylonians and Persians and their religions. These apocalyptic times exposed a flourish of 'angel' appearances, mostly to represent or mediate the intervention of Israel's God, Yahweh in times of severe crisis.

\section{Appearance in different forms}

One of the most striking questions is: how do 'angels' and heavenly beings look like? No definition or textual description in the Hebrew Bible clarifies this question with certainty. Textual evidence emanates that they were people of 'flesh and blood' (Gen 18:2; Dan 8:15) or supernatural beings, like God (Gen 48:16). Angels also appeared from a burning bush in flames of fire (Exod 3:2; Judg 13:20), in a pillar of cloud (Exod 14:9), in winds (Ps 104:4), as stars or other created heavenly bodies (Ps 148:2), and as a human messenger (Mal 3:1). Child-like figures with wings and haloes are nowhere to be found in Hebrew Scriptures. Nonetheless, they are distinct from other figures with wings, namely Seraphim (Isa 6:2 ea) and Cherubim (Ezek 1:6ff).

The role and function that 'angels' fulfilled in ancient times rather give indication of who they were. Mostly they were part of scenery and narratives, which expose who God is, what God had done or how God had dealt with people. 'Angels' had therefore strongly been related to the Israelite God, Yahweh. In the different forms of their appearances, they thus emphasized aspects of the work of this Israelite God.

\section{Ancient Near Eastern pantheon}

Ancient Israel had no monopoly on the existence and appearance of 'angels' and other heavenly beings. As late newcomer to this Ancient Near Eastern (ANE) world of cultures and religions in the Late Bronze/Early Iron ages (+- $1200 \mathrm{BCE})$ the nation Israel discovered that their neighbours in Canaan, Syria, Mesopotamia, and Persia were already acquainted with these beings in their religions and divine narratives (myths). In the Ancient Near Eastern regions and in the Hebrew Bible the word for 'angel', namely mal'âk, was widely attested. The term refers to both human and supernatural emissaries / messengers. Although the Israelite faith around Yahweh developed as a unique, independent entity over centuries, the Israelite culture, religion and faith descriptions had been influenced by the concepts, language (images, metaphors) and motifs of their neighbouring nations. 
In a polytheistic Ancient Near Eastern environment, Israel encountered a divine pantheon, where a hierarchy of divine beings/gods owned and governed the cosmos, different areas of life, including human beings. The appearance of such a divine pantheon in the heavenly realm seemed to be constructed as a mirror image of the earthly realm with its hierarchical constructed society, where there were kings, royal families, ordinary citizens and messengers or slaves. An example of such a pantheon became evident from the narratives reflecting the Baal religion centred around the Baal temple and cult at Ugarit, Syria. In Ugarit (also known as Rash Shamra), a metropole of the north-west Semitic cultures, the concept of a divine pantheon unravels a four-tiered structure of gods and divine beings to position angels or 'messenger'-beings within this 'divine' world. This posited a 'worldview', according to which ancient peoples oriented themselves towards their belief system (Handy, 1995:32-36).

The four-tiered hierarchical structure mirros following societal layers:

- The highest ruler(s) and aristocratic nobles: the king and mother queen;

- Powerful rulers, governing class, and landowners who served the highest class;

- Royal workers with expertise and skills, serving the upper class;

- Slaves and messengers of society without any personal volition.

These layers determined the status and responsibilities of the incumbents of the different levels. Furthermore, they translate to the following hierarchical structure of the heavenly realm Handy, 1995:34-36):

- Powerful and authoritative god(s); For example, El and Ashera (mother and queen goddess);

- Active deities who argue, fight, or abuse: Baal, Anat, Yam, Mot, Shapshu;

- Craft deities with skills and expertise, who served the upper class: Kothar-wa-Hasis ea;

- Slaves and messengers of the divine realm, who were not independent, but in service of the upper class: the god Gpn w ugr. Ugaritic texts call them ilm (gods), but of a different rank. As messengers of a lower rank these beings fulfilled auxiliary functions in service of the higher gods. In ancient Mesopotamia (Akkad, Sumer) similar trends prevailed.

The earthly king was on the lowest rank in this hierarchy. As a bridge between the heavenly and earthly realms the king was often known as the 'child' or 'son' of the god(s). ${ }^{1}$ In Egypt and Babel the king was even regarded as a deity in this office.

Despite the unique and independent development of the Israelite faith over more than a millennium, this concept of pantheon only provides a paradigm and worldview through which this faith could be understood (Blenkinsopp, 1986:354-366). The Hebrew Bible reflects Israel's own religious identity, with Yahweh ultimately as a monotheistic god - the only existing, universal deity, with all other creatures - including other deities- subordinate to and in service of him (Gnuse, 1979:177-229). Monotheism as a belief system in the existence of one God only has developed over six centuries "from monolatry in a polytheistic reference system to the emergence of absolute monotheism in/after the Babylonian exile" (Human, 1999:491-503),

With resemblances and differences, the Yahweh-faith in Israel recognized only the first and fourth layers of the Ugaritic pantheon, with absence of the second and third tiers (Handy, 1995:37). Even the messengers or 'angels' of the fourth tier are regarded as less divine in Israel than their Ugaritic counterparts. In the Hebrew Bible, the notion and function of this pantheon with angels as messenger-beings are evident. Motifs and metaphors are used and alluded to (Deut 32:8; $1 \mathrm{Kgs} 22: 19 \mathrm{ff} ;$ Job 1:6; Ps 82:2ff) of which the most notable is images

\footnotetext{
${ }^{1}$ See for example, 2 Sam 7:12-13 and Ps 2:7, where the king is described as 'son' of God.
} 
of the ruling king-God (Deut 32:8), the 'divine council' (Job 1:6; Ps 82) and the 'sons of the gods' (Gen 6:1-4; Ps 2). ${ }^{2}$

\section{Multiple divine involvement}

Throughout history the Israelite God, Yahweh, had spoken, acted and intervened in various ways with people and creation. This include:

- divine appearances to Moses (Exod 33:9), God's people Israel (Exod 19:17) and the prophets (Ezek 1) through a cloud, thunderstorm, wind or even dreams and visions;

- interventions in nature and history, like the ten plagues (Exod 7-10), and Reed Sea deliverance deeds (Exod 14-15);

- direct communication with people like Abraham (Gen 17:11-2), Jacob (Gen 35:9), Moses (Exod 19:3-6), Samuel (1 Sam 3:11-14), Solomon (1 Kgs 3:5) Isaiah (Isa 6:9), Jeremiah (Jer 1:5) and many others;

- involvement and activities of 'angels' or other divine beings, inter alia the 'angel' of Yahweh, sons of the gods (Gen 6; Job 1-2; Ps 82). ${ }^{3}$

From a plethora of examples angels fulfilled the following roles and functions in the Hebrew Bible. Being referred to as mal' āk or mal' àkim (literally: 'to send someone') these beings primarily had a messenger function (Ficker, 1984:901-904; Newsom, 1992:463-464; Seebass, 1993:583-585; Meier, 1998:47-50; Haag, 2009:647-648).

- They were human and divine messengers - Jacob sent messengers to Esau (Gen 32:3); angels bring Yahweh's message to prophets (2 Kgs 1:3; Isa 6; Jer 23:18), while Yahweh sent prophets as messengers to Israel (Jer 44:26; Mal 3:1) ;

- They were God's 'arm' of deliverance and protection - angels supported, encouraged and protected both Israel and individuals (Exod 14:19; 23:20; 23; 33:3); in her distress and fear the angel supported and protected Hagar, the wife of Abraham (Gen 21:17); the angel of Yahweh prevented Abraham from killing his son Isaac (Gen 22:13); the same angel rescued residents of Jerusalem by killing 185000 Assyrians (2 Kgs 19:35; Isa 37 36); similarly this angel of Yahweh protected and delivered those who fear the God, Yahweh (Pss 34:8; 91:1)

- They acted as God's punishing 'hand' - this hand of doom struck unacceptable behaviour (Gen 19:13), both Jerusalem -70 000- and God's enemies (2 Sam 24:16; $1 \mathrm{Chr} 21: 12$; Ps 35:5); also Pharaoh and the Egyptians with all their firstborns (Ps 78:49);

- They proclaimed God's praise - as part of creation 'mighty angels' are called upon to praise God for creation and deeds of deliverance (Pss 103:20; 104:4; 148:2);

- They were involved in the well-being of everyday activities - the angel brought comfort to women about the future and their unborn children (Gen 16:7; 21:18; Judg 13:3); an angel sought a wife for Isaac (Gen 24:7, 40); prevented Abraham from killing

\footnotetext{
${ }^{2} 8$ When the Most High gave the nations their inheritance, when he divided all humankind, he set up boundaries for the peoples according to the number of the sons of Israel. (Deut 32:8 NIV);

${ }^{19}$ Micaiah continued, "Therefore hear the word of the LORD: I saw the LORD sitting on his throne with all the multitudes of heaven standing around him on his right and on his left. ${ }^{20}$ And the LORD said, 'Who will entice Ahab into attacking Ramoth Gilead and going to his death there?' "One suggested this, and another that. ${ }^{21}$ Finally, a spirit came forward, stood before the LORD and said, 'I will entice him.' (1 Kgs 22:19-21 NIV);

God presides in the great assembly; he renders judgment among the "gods": 2 "How long will you defend the unjust and show partiality to the wicked? (Ps 82:1-2 NIV);

the sons of God saw that the daughters of humans were beautiful, and they married any of them they chose (Gen 6:2 NIV).

${ }^{3}$ See Ficker (1984:900-908) and Newsom (1992:462) for a variety of terms.
} 
Isaac (Gen 22:11); and prevented Balaam to curse Israel, but rather blessed them (Num 22:38);

- Other activities include announcement of births (Gen 16:11-12), to bring messages of reassurance (to Jacob - Gen 31:11-13), to commission people for tasks (Gideon Judg 6:11-24), and to change and guide people's behaviour (Balaam - Judg 2:1-5).

Angels functioned mostly for the sake of their message "to serve God and to execute God's will" (Newsom, 1999:461). Not much interest was demonstrated in individual angels, when they operated. Normally no personal names or offices were attributed to them. When people reacted to their agency, there was often no reaction (Gen 19), only sometimes reverence (Joshua - Jos 5:14-15) or fear (Manoah - Judg 13:21).

In the Second Temple period (after 520-515 BCE) new developments regarding angels appeared, as is known in different genres of literature and in different communities (for example apocalyptic literature and the Qumran community). These beings had different meanings in different Jewish communities (Newsom, 1999:466).

Only two angels were called by their names in the Hebrew canon and one in deutero-canonical literature (Haag, 2009:647). In the apocalyptic literature of the second century (+-165 BCE) the arch-angel Michael ("Who is like God") was helping the covenant people, Israel, in their suppression and distress during the so-called end-times (Dan 10:13, 21; 12:1; also Rev 12:7). ${ }^{4}$ Another arch-angel, Gabriel ("Man of God"), explained Daniel's end time vision (Dan 8:16: 9:21; also Luk 1:19, 26), when Israel was in life-endangerment. Raphael ("God heals"), also belonging the category of arch-angels in late-Judaic literature, healed Tobias, and accompanied him. ${ }^{5}$ Raphael was also one of seven angels who brought the prayers of holy ones up to the glory of God. All three these arch-angels appeared to be instruments of divine actions like delivering, supporting healing and messaging.

\section{Angel of Yahweh / Elohim (God)}

The 'angel' of Yahweh / God 6 seems to be distinct from other angels (Ficker, 1984:904-908; Röttger, 1991:539-541). This distinction between these two agents (angels and angel of God) is not always clear in texts. This angelic being appears in many Old Testament problematic texts and was either a human being or a divine figure (Meier, 1998:54-59). It so happened that the angel of Yahweh was the personification of Yahweh himself (Exod 3:2-4), while in other instances this 'angel' was more distant from, albeit in service of God. This ambiguity which characterises the appearance of this divine being either indicates the presence or distance of Yahweh in different texts (Exod 32:34; Num 20:16).

The story of Abraham, Sarah and Hagar in Genesis 16 illustrates this ambiguity or interchangeable character between Yahweh and his angel. Dialogue between Hagar, the angel and Yahweh seems as if Hagar speaks with the angel, but then suddenly the communication is with God self, when she addressed the Name of God. ${ }^{7}$ Many other examples illustrate this phenomenon (Gen 18:2ff, 33-19:1; 21:15-21; 22:11-12; 31:11-13; 48:15-16; Exod 3:2-6; Judg 6:11-24). This presence of God is often portrayed as subtle (Exod 14:9; 20:20-23), like the (so-called deuteronomistic concept of the) Name of God, which expresses

\footnotetext{
${ }^{4}$ Michael's name also appears in the book of Judith, a deutero-canonical book.

${ }^{5}$ See the book of Tobit (Tob 3:25; 5:19; 12:15).

${ }^{6}$ See Ficker (1984:901): "the expression mal' āk YHWH (always singular) occurs 58x: Gen 16:7, 9-11; 22:11, 15: Exod 3:2; Num 22:22-35, 10x; Judg 2:1, 4; 5:23; 13:3-21, 10x; 2 Sam 24:16; 1 Kgs 9:7; 2 Kgs 1:3, 15; 19:35 = Isa 37:36; Hag 1:13; Zech 1:11f.; 3:1, 5f.; 12:8; Mal 2:7; Pss 34:8; 35:5f.; 1 Chr $21: 12,15 f ., 18,30$. The combination mal' āk (ha) Elohim is attested 11x: Gen 21:17; 31:11; 32:2; Exod 14:19; Judg 6:20; 13:6, 9; 1 Sam 29:9; 2 Sam 14:17, 20; 19:28; also in pl. Gen 28:12; 32:2."

7 See Gen 16:7-12 versus Gen 16:13.
} 
his presence in the Jerusalem Temple in texts after the exile, when God was experienced by his people as remote, distant or even absent.

Several reasons are offered for the ambiguity and exchangeability between God and his angel(s). ${ }^{8}$ The most convincing is that it causes a paradox or tension which confirms the authority, presence and intervention of God on the one hand, but the realisation that human beings cannot encounter God unmediated, on the other hand (Newsom, 1992:464). (Except for Moses) nobody can see God face to face and remain alive (Exod 33:11, 20). Therefore, in these cases the angel of Yahweh is identical with God self and God's work in a subtle appearance.

\section{Seraphim and Cherubim}

The Hebrew Bible also records other 'angel'-like beings. They are seraphim and cherubim (Röttger, 1991:537; Haag, 2009:647). How did they look like, and what were their functions?

Seraphim appear only in the calling vision of Isaiah (Isa 6:2,6) in the Hebrew Bible. The origin and meaning of this name is unknown. Together with the cherubim they are regarded as guardians of the divine throne (Ark of the Covenant) ${ }^{9}$ in Israel. In Isaiah they guarded the throne, praised and worshiped God and executed a purification rite (Isa 6:6). Apparently in human form they had six wings: two wings covered their faces, two covered their feet, and with two they were flying. These human-animal-like figures accompanied the presence and appearance of God, but is separate from and subordinate to God. They performed serving, guarding and worshipping functions in God's presence.

Cherubim were prominent as symbolic figures in the Ancient Near East. They were known in Egypt and Mesopotamia from religious texts, sculptures and ornaments in temples or palaces, and guarding figures at entrances of buildings and gates (Keel, 1972:110, 124, 126). As symbols of deities and rulers they often express the cruelty of rulers and the heavenly reality of their power.

These symbolic and heavenly beings appear frequently in the Hebrew Bible, mostly to accompany the presence of Yahweh (Keel 1972:146-149). Their descriptions are not always the same. Visions in Ezekiel described them as mixed human and animal-like figures, once with two faces: one face like a human being, and the other like a lion (Ezek 41:18). Another vision depicts each cherub with four faces and four wings (Ezek 10:21), and under their wings was what looked like human hands. Each of the cherubim had four faces: one face was that of a cherub, the second the face of a human being, the third the face of a lion, and the fourth the face of an eagle - almost monster-like descriptions. Despite these different depictions of how they looked like, the cherubim accompanied the mighty presence and glory of God above them.

In addition, the cherubim fulfilled a guarding and protecting function (Röttger, 1991:537). God placed cherubim to guard the Garden of Eden and the way to the 'tree of life' (Gen 3:24). For a similar function two golden cherubim on both sides of the Ark of the Covenant protected symbolically the holy objects inside, with the spread wings over the case as footstool of the invisible enthroned God above it in heaven (Exod 25:18-22, 37; $1 \mathrm{Kgs} 8$ ). ${ }^{10} \mathrm{~A}$ regular image in the Hebrew Bible is that Yahweh is enthroned above the cherubim (2 Kgs 19:15; 2 Chr 13:6;

\footnotetext{
${ }^{8}$ See Hirth (1975:13-23) and Newsom (1992:464): the angel is described as hypostasis of Yahweh; a functional identity exists between the two; the notion of the mal'āk Yahweh is a later insertion in texts; that the alteration of the two agents has to do with 'point of view'.

${ }^{9}$ This throne was symbolically the Ark of the Covenant, on which the feet of Yahweh rested mythologically. The ark was situated in the 'Most Holy' of the temple.

${ }^{10}$ Several images of the cherubim appeared in the tabernacle and the temple (Exod 26:31; 36:8; $1 \mathrm{Kgs}$ 6:23-35; 2 Chr 3:7).
} 
Is 37:16; Pss 80:2: 99:1) as Cherubim Thronender (Enthroned One), the one who is mythologically enthroned as king in heaven, with his feet on the footstool / cherubim wings. In contrast to the Ancient Near East the cherubim in Israel were not associated with earthly dwellings / buildings, but with God's heavenly reign, presence, protection and glory.

\section{Fallen angels and 'the' Satan}

The Hebrew Bible does not know or reflect on the concept of 'fallen angels'. Such an idea would have been absurd for the Yehudite community (Handy 1995:37). Texts like Ezekiel 28:12-27 and Isaiah 14:12-14 are often wrongly applied to underpin such an idea (Human, 1997:50-52). 'Fallen angels' is rather a concept, which was developed in the periods of early Judaism and Christianity. Also the notion of the Satan is not related to a fallen angel in Hebrew Scriptures. References to (the) Satan all indicate the descriptive role of an accuser, opposer or adversary, as subordinate to Yahweh (Breytenbach \& Day, 1999:726-730; Newsom, 1999:466). In text references to 'the' Satan (Job 1:6-9; 2:2-7; 1 Chr 21:1; Zech 3:1-2) only the Chronicles text (1 Chr 21:1) comes closest to a proper name for a deceptive agent (the name Satan without an definite article), when a re-reading of the 2 Samuel 24 story in the Persian / Hellenistic times (late $6^{\text {th }}-4^{\text {th }}$ centuries BCE) might have personilsed the origin or power of evil. This is nonetheless, not the devil of later New Testament times.

\section{Final perspective}

From the above perspectives it seems likely that 'angels' and other heavenly beings or symbolic earthly representations of transcendent divine agents are subordinate to the High God of the ancient Near Eastern belief system(s) and to the God, Yahweh, of the Hebrew Bible. Angels have an auxiliary function as messengers of the gods in ANE religions and gives direction to God's actions and interventions in the Hebrew Bible. Therefore, angels in the ANE or in the Hebrew Scriptures are not objects of divine reverence or worship. The profile of their being is pluriform, vague and allusive. Thus, there is no uniform picture of 'angels' in the Hebrew Bible (Röttger, 1991:538).

\section{DIVINE BEINGS AND ‘ANGELS’ IN AFRICAN RELIGIOSITY?}

\section{Introduction}

Perspectives on 'angels' in ancient Near East and in the Hebrew Bible enquire also into the realities of the 'seen' and the 'unseen' in Africa and African Traditional Religions (ATR). Without determining the relationship between the former and the latter, the question arises whether similar figures or functions of angels or angelic beings can be identified in African Traditional Religions. Being aware that a (one) unified African religious system does not exist and that different cultures offer multiple varieties or deviations of African religiosity, this presentation offers only a few perspectives with the help of specialised African scholars ${ }^{11}$ to identify such agents or functionaries and their function(s). ${ }^{12}$ This attempt of a very short outline of concepts in African Traditional Religions has no intention to enforce the concepts of the ancient Near East or the Hebrew Bible on the ATR, but to identify and understand possible 'similar' divine agents and their religious function in all three categories.

\footnotetext{
11 In this part I am indebted and recognise the analysis, perspectives and contribution of especially EC Ekeke and CA Ekeopara (2010:209-218), and others.

12 It is further not the intention of this essay to focus on traditions in Africa, like Ethiopia or to describe the influence of the traditions of the ancient Near East and Hebrew Bible on the ATR's. Both the former and the latter had their own development. Like in the case of the former, the latter also shows multiple regional and contextual varieties.
} 
It might be true that the Abrahamic religions (Judaism, Christianity and Islam) had an influence on African religiosity via the inter-connections of trade relations, migration of people, colonialism or other means. Nonetheless, the intention of juxtapositioning the three belief systems in this essay is to create a framework of comparison of the functions of the divine 'unseen' and seen agents/functionaries (angels) in creation and in the lives of human beings. It is not to prove that African religiosity is in need ancient Near Eastern religions or the Hebrew Bible for the functioning of their belief systems.

\section{Supreme Being (God), divinities and spirits}

\subsection{Introduction}

In African Traditional Religions (ATR) a so-called traditional African worldview is apparent (Chemorion, 2014:12-17). There are various religious dimensions of this African worldview (Chalk, 2006:190-198). ${ }^{13}$ The worldview becomes evident in "traditional narratives, proverbs, wise sayings, and the rituals performed by specialists such as priests, rainmakers, and officiating community leaders" of African cultures and peoples (Chemorion, 2014:12). This worldview saturates every aspect of life and human activity of the African.

This worldview divides the universe between the 'world above' and the 'world below'. God inhabits the 'world above'. In the 'world below' there are two areas, namely the area of humans and the area of spirits. This paradigm also constitutes the worlds of the 'seen', and the 'unseen'. As part of a view of causality God is the supreme power and controller over creation, while humans, ancestors, divinities and spirits manipulate and determine daily life activities. The interaction between humans and spirits determine the well-being or ill-being of the former. Spirits can either be the ancestors ('living dead'), or those without family ties and who occupy "rocks, trees, lakes, streams or animals" and those who harm, hurt and punish humans, like witches (Chemorion, 2014:14-17). The categories of Supreme Being (God), divinities, and spirits are therefore known in ATR.

\subsection{Supreme Being (God)}

In African religiosity God is real to Africans (Ekeke \& Ekeopara, 2010:210-213). This Supreme Being has ascribed attributes like transcendent, immanent, eternal and immortal. He has no beginning or end; is far and near, in the front and in the back. He is a living eternal being and a unique incomparable God. His unique character allows no images of his being, but symbolic representations appear abundantly. Different African cultures and traditions describe the Supreme Being with a plethora of depictions (eg. King, Chief, Owner of heaven, creator ea). Several more attributes appear in folklores, short stories, sayings, myths, proverbs, ceremonies and rites of African people: they include omnipresent, omnipotent, and omniscient, $\mathrm{He}$ is One entity in African Traditional Religions, He is good, merciful and holy. The relationship between the Supreme Being and the other categories describe the character, nature and function of the other entities.

\subsection{Divinities}

Apart from God as Supreme Being, there is a group of divine beings known as divinities (Ekeke \& Ekeopara, 2010:213-216). It seems that the idea of pantheon with divinities is real, at least, in parts of Africa (Nigeria and Sudan), although not everywhere on the continent (Njoku 2002:125). This second layer of divinities and deities are either created by God (Mbiti, 1969:75-76) or "brought out into being" (Idowu 1973:169), but they are subordinate to the Supreme Being. Scholars also distinguish between primary and minor divinities. There are numerous divinities, who are often named as 'gods', semi-gods', 'nature spirits', 'divinities',

${ }^{13}$ Chalk (2006:190-198) distinguished the experiential, mythic, doctrinal, ethical, ritual and social dimensions of the ATR worldview. 
deities, etc. Mbiti (1975:117) describes these divinities as "personification of God's activities and manifestations, the so-called nature spirits, deified heroes and mythological figures". Therefore they are divided into two groups, namely 'spiritual beings' and 'human beings'.

As derivations of the Supreme Being they receive their authority to function and perform from God to be "functionaries in the theocratic government of the universe" (Idowu 1973:170). They are responsible for various areas in nature (thunder, earth, solar bodies, rain) and life (mother role, father relationship, wealth, children, fertility, medicine), and have in many instances local names. An arch-divinity in West Africa made one of his children 'the divine messenger and inspector-general in African pantheon' (Idowu 1973:80). This alludes to the same function of 'angels' in the Ancient Near Eastern pantheon and in the Hebrew Bible (Old Testament).

Divinities, who are represented on earth with images, temples or shrines, perform intermediatory functions between the Supreme Being (the 'unseen') and humankind (the 'seen'). They "have become channels through which sacrifices, prayers and offerings are presented" to the Supreme God (Ekeke \& Ekeopare 2010:215). It could therefore be interpreted that the roles of biblical angels and the angel of Yahweh can be captured in the mediatory functions of (some of) the African 'deities and divinities'.

\subsection{Spirits}

Spirits form an own category and are similarly 'created' entities (Ekeke \& Ekeopara, 2010:216217). They are separate from divinities (Idowu 1973:173) and are described as "non-descript, immortal and invisible, but they could incarnate into material 'bodies'14 to be visible for specific purposes. In many African narratives they are portrayed in human form, activities and personalities (a change from the 'unseen' into the 'seen'). In some of their functions they can either cause harm on human beings ${ }^{15}$ or inspire people to prophesy. Therefore, both evil and guardian spirits operate in African religiosity; the latter to protect and to bring prosperity and good luck to people.

\section{FINAL SYNTHESIS}

Several portraits have been painted of angels and divine beings in the Ancient Hear East and angels/angel of Yahweh in the Hebrew Bible (Old Testament). Similarly a very short survey portrayed the religious belief system in African religiosity. In an assessment of the above described belief systems the following aspects seem evident:

- The Ancient Near Eastern (ANE) belief system(s) reflect four tiers of divine agents (authoritative gods, active deities, craft deities, messenger - angelic - beings);

- The Hebrew Bible (Old Testament) reflect two tiers of divine agents (God, messenger - angelic - beings);

- In the African Traditional Religion(s) (ATR) there are basically three tiers ${ }^{16}$ of divine being (Supreme Being, divinities, spirits);

- It seems convincing to allege that some roles of divinities and spirits in (at least) some exponents of the ATR fulfil similar functions as the angels or the angel of Yahweh of the ANE and Israelite religion. How it happens in each of the different systems in Africa

\footnotetext{
${ }^{14}$ Ekeke \& Ekeopare (2010:216) distinguish three sources of spirits. Spirits are created as a special race, or they are the remains of human beings when they die, or they are the souls or spirits of animals who died.

${ }^{15}$ In this regard the spirit of witchcraft is real active and powerful and can be very dangerous (Idowu, 1973:175-6),

${ }^{16}$ Since the African Traditional Religions' belief system(s) are complex, diverse and not a unitary system, there are probably not only three tiers in all ATR's, but more. My suggestion of three tiers is a simplistic choice for the sake of relating the functions of 'angelic' kinds of divine agents in the different belief systems of the ancient Near East, the Hebrew Bible and the ATR's.
} 
may differ, but the role and function of angels/angel of Yahweh in the Hebrew Bible and of ATR's divinities and spirits in Africa are very similar.

Further in-depth research is necessary to expose more detail. Hereby the interaction between the 'seen' and the 'unseen' in all the above faith systems seems to be real for their adherents. This interaction between humans and is either life-giving or devastating for inhabitants of the earthly realm.

\section{References}

Balz, H.R. ea. (Hg). (1993). Theologische Realenzyklopädie. Band 9. Walter de Gruyter, Berlin, New York.

Breytenbach, C. \& Day, P.L. (1999). Satan. In K. van der Toorn, B. Becking, B. \& P. van der Horst, P. (Eds.). Dictionary of Deities and Demons in the Bible. Eerdmans Pub. Co., Grand Rapids, MI. 726-732.

Blenkinsopp, J. (1986). Yahweh and Other Deities. Conflict and Accommodation in the Religion of Israel, Interpretation, 60/4, 354-366.

Chalk, J.P. (2006). Genesis 11 and the African worldview: conflict or conformity? Published thesis submitted for the degree DLitt et Phil, UNISA, Pretoria.

Chemorion, D.C. (2014). Introduction to Christian worldview. Meaning, origins and perspectives. Nairobi Academic Press, Nairobi.

Ekeke, E.C. \& Ekeopara, C.A. (2010). God, divinities and spirits in African traditional religious ontology. American Journal of Social and Management Sciences, 1/2, 209-218.

Ficker. R. (1984). Mal' āk. Bote. In E. Jenni \& C. Westermann (Hg.). Theologisches Handwörterbuch zum Alten Testament (THAT), Kaiser Verlag, München. 900-908.

Freedman, D.N. (Ed). (1992). Anchor Bible Dictionary, Volume I. A-C. Doubleday Dell Co., New York, London Toronto.

Görg, M. \& Lang, B. (Hg). (1991). Neues Bibel-Lexikon. Band I. A-G. Benzinger Verlag, Zürich.

Gnuse, R.K. (1979). No other Gods. Emergent Monotheism in Israel (JSOT 241). Sheffield Press, Sheffield, 177-229.

Haag, E. (2009). Engel. II Biblisch. In W. Kasper (Hg). Lexikon für Theologie und Kirche. Band 3. Dämon bis Fragmentenstreit, Herder Verlag, Freiburg, Basel, Wien. 646-648.

Handy, L.K. (1995). The Appearance of Pantheon in Judah. In D.V. Edelman (Ed.), The Triumph of Elohim. From Yahwisms to Judaisms, Pharos, Kampen, 27-43.

Hirth, V. (1975). Gottes Boten im Alten Testament. Theologische Arbeiten 32, Evangelische Verlagsanstalt, Berlin.

Human, D.J. (1997). Engele en ander hemelwesens: enkele pennestrepe vanuit die Ou Testament. In S.J. Joubert \& J.G. van der Watt (reds.), Hy sal sy engel voor jou uitstuur, CUM, Vereeniging, 32-52. 
Human, D.J. (1999). Aspects of Monotheism: A continued debate, Old Testament Essays 12/3, 491-505.

Idowu, E.B. (1973). African Traditional Religion. A definition. SCM Press, London.

Jenni, E. \& Westermann, C. (Hg.). Theologisches Handwörterbuch zum Alten Testament (THAT), Kaiser Verlag, München.

Kasper, W. (Hg.). (2009). Lexikon für Theologie und Kirche. Band 3. Dämon bis Fragmentenstreit, Herder Verlag, Freiburg, Basel, Wien.

Keel, O. (1972). Die Welt der altorientalischen Bildsymbolik und das Alte Testament, Benzinger / Neukirchener Verlag, Neukirchen-Vluyn.

Mbiti, J. (1969). African Religions and Philosophy, Heinemann, London.

Mbiti, J. (1975). Concepts of God in Africa, SPCK, London.

Meier, S.A. (1999). Angel I. In K. van der Toorn, B. Becking \& P. van der Horst (Eds.). Dictionary of Deities and Demons in the Bible. Eerdmans Pub. Co., Grand Rapids, MI. 45-50.

Meier, S.A. (1999). Angel of Yahweh. In K. van der Toorn, B. Becking, \& P. van der Horst (Eds.). Dictionary of Deities and Demons in the Bible. Eerdmans Pub. Co., Grand Rapids, MI. 53-59.

Newson, C. (1992). Angels (Old Testament). In D.N. Freedman (Ed). Anchor Bible Dictionary, Doubleday Dell Co., New York, London Toronto, ea. 461-468.

Njoku, F.O.C. (2002). Essays in African Philosophy. Thought and Theology. Claritian Institute of Philosophy and Clacom Communication, Owerri.

Röttger, H. (1991). Engel (AT). In M. Görg \& B. Lang (Hg). (1991). Neues Bibel-Lexikon. Band I. A-G. Benzinger Verlag, Zürich. 537-538.

Röttger, H. (1991). Engel Jahwes. In M. Görg \& B. Lang (Hg). (1991). Neues Bibel-Lexikon. Band I. A-G. Benzinger Verlag, Zürich. 539-541.

Seebass, H. (1993). Engel. Il Altes Testament. In H.R. Balz ea. (Hg). (1993). Theologische Realenzyklopädie. Band 9. Walter de Gruyter, Berlin, New York. 583-586.

Van der Toorn, K., Becking, B. \& Van der Horst, P. (Eds.). (1999). Dictionary of Deities and Demons in the Bible. Eerdmans Pub. Co., Grand Rapids, MI. 